\title{
Bricks to Bones: Royal Women and the Construction of Holy Place in the Stepennaia Kniga ${ }^{1}$
}

\author{
Rosie Finlinson \\ Department of Slavonic Studies, University of Cambridge, U.K., \\ rf303@cam.ac.uk
}

\begin{abstract}
This essay explores the symbolic envisioning of the royal woman in the sixteenth-century Muscovite "Book of Royal Degrees." It argues that the princesses figure as carriers not only of royal heirs but also as signifiers of spiritual capital and territorial legitimacy for the ruling dynasty, as they map the physical and spiritual borders of Orthodox Muscovy through their association with holy sites. The terms of their veneration move with the geo-political imperatives of the text, and the consolidation of political power in the Kremlin manifests itself in the body, and eventually the womb, of the woman carrying the Muscovite autocrat.
\end{abstract}

Keywords: female sanctity; Early Modern Russia; Book of Royal Degrees; place; body.

1 I would like to thank CEELBAS AHRC Centre for Doctoral Training for funding this research.

This is an Open Access article distributed in accordance with the Creative Commons Attribution Non Commercial (CC-BY-NC-ND 4.0) license, which permits others to copy or share the article, provided original work is properly cited and that this is not done for commercial purposes. Users may not remix, transform, or build upon the material and may not distribute the modified material (http://creativecommons.org/licenses/by-nc/4.0/) 


\title{
Bricks to Bones: Royal Women and the Construction of Holy Place in the Stepennaia Kniga ${ }^{1}$
}

\author{
Rosie Finlinson \\ University of Cambridge, United Kingdom
}

\section{Introduction}

The Stepennaia Kniga or the "Book of Royal Degrees" (hereafter SK) is a sixteenth-century historical compendium produced under the rule of Ivan IV of Muscovy. ${ }^{2}$ Work on the $S K$ began around the mid-1550s and it was compiled between 1560 and 1563. The $S K$ is the first chronicle-style text which aims to construct a coherent historical narrative for the ruling dynasty, the Riurikids, beginning in tenth century in Kiev and culminating in sixteenth-century Moscow. It presents the history of the Riurikid dynasty as one of god-ordained rule over a singular and cohesive territory united by faith, where the process of succession is unilateral. The $S K$ narrative thus aligns contemporary Muscovite dynastic, ecclesiastical, and territorial ambitions. To do this, it is obliged to pass over the reality of collateral succession and periods of dynastic strife and territorial disunity, which in reality dominated the geo-political culture of Kievan Rus and later Muscovy right into the fifteenth century. The $S K$ is compiled in a period when the rule of a single autocrat is being established, and his seat located firmly in Moscow. Ivan IV was the first ruler to be crowned "Tsar," a title which

\footnotetext{
${ }^{1}$ I would like to thank CEELBAS AHRC Centre for Doctoral Training for funding this research.

2 I use the term 'Muscovy' broadly to refer to the pre-modern polity which had its centre in Moscow from the late thirteenth century until the eighteenth century, when it became the Russian Empire. The Stepennaia Kniga consistently emphasizes continuity between Muscovy and Kievan Rus, the medieval principality which preceded the Muscovite State and had its centre in Kiev (late ninth to mid-thirteenth centuries).
} 
was reserved previously for Christ, biblical kings and the Byzantine Emperor. During his reign, Ivan launched a number of imperial campaigns to expand the borders of his Orthodox state. ${ }^{3}$ Accordingly, the $S K$ seeks to underline the belonging of disparate marginal territories to the unified lands of "Holy Rus."

This study explores how women fit into the SK's conceptualisation of dynastic lineage. The compendium is composed of seventeen sections, or 'Royal Degrees' of rulership, each focusing on the reign of a major ruler from Vladimir, who 'baptised' Rus in 988, to Ivan IV. The opening passage states that it relates tales of Prince Vladimir's offspring, of whom "many...both of the male and female sex, pleased God in blessed rulership and marriage." 4 Yet, contrary to this claim, in a narrative covering 700 years of history there are fewer than ten accounts of women which describe their attributes and activities, or which constitute anything other than brief statements of marriages, births, and deaths.

I focus mainly on three royal women, whose pious behaviour the $S K$ elaborates in the greatest detail. These women are all venerated as holy figures and have hagiographic or semi-hagiographic accounts dedicated to them in which their actions and miracles are celebrated. The first is Olga of Kiev, a tenth-century princess whose hagiography forms the preface to the SK. Olga was the first member of the dynasty to adopt the Christian faith, and is the grandmother of Prince Vladimir, who converted Rus to Christianity in 988. The second is Evfrosiniia of Polotsk (Ch.11, Degree V, twelfth century), a Russian princess who founded two monasteries and undertook a pilgrimage to Jerusalem. The third is Evdokiia Donskaia (Ch.14-20, Degree XII, fourteenth century), wife of Moscow Grand Prince Dmitrii Donskoi (reigned 1359-1389), who is celebrated for her miracle-working in and around the Kremlin. I also briefly mention a fourth royal woman: Mariia Shvarnovna (Ch.10, Degree VI, twelfth century), wife of Vsevolod, Grand Prince of Vladimir (reigned 1177-1212). However, Mariia Shvarnovna features

\footnotetext{
3 S. Bogatyrev, "Ivan IV (1533-1584)," in The Cambridge History of Russia Volume I: From Early Rus' to 1689, ed. Maureen Perrie (Cambridge, 2006), 245.

4 Stepennaia Kniga Tsarskogo Rodosloviia po drevneishim spiskam [The Book of Degrees of the Royal Genealogy: a Critical Edition Based on the Oldest Known Manuscripts, Volume 1] (Hereafter SK Tom I, SK Tom II, SK Tom III), ed. Gail D. Lenhoff and Nikolai N. Pokrovskii (Moscow: "Languages of Slav Cultures," 2007), 147.
} 
less in this study as she is not celebrated as a saintly figure and the $S K$ allocates only a single heading to the description of her life (as opposed to seven in the case of Evdokiia Donskaia, and full hagiographies in the cases of Olga of Kiev and Evfrosiniia of Polotsk). ${ }^{5}$

It is difficult to categorise the political and spiritual roles of the royal women in the way that can be done with the male figures, who occupy fixed ecclesiastical and political positions such as "Grand Prince," "martyr," "Metropolitan" and others from which women are mostly excluded. It is evident that epithets describing the dynastic women do not indicate, as they do for men, for what reason a given figure is perceived as being holy. A.S. Usachev has noted that most of the female representatives of the dynasty are addressed only with epithets that reflect their moral characteristics, such as "blessed" or "righteous," whereas their male counterparts are additionally described by epithets linked to rulership, such as "sceptre-bearing." Moreover, the application of these epithets is not consistent. All we can conclude is that these women are all members of the dynasty. However, in what way this is integral to their importance in the $S K$ is also under question. Not all of the women mentioned trace their lineage directly to Ivan IV, but in some cases are part of disparate branches of the Riurikid dynasty. Not all referred to as "princesses," as we see in the case of the eleventh-century princess Evfrosiniia of Polotsk, addressed singularly as "abbess." Not all of them are wives to Grand Princes or mothers to the princes of the dynasty. The epithet of "blessed spouse" is occasionally applied, but not consistently. It is not, for example, applied in the cases of Olga of Kiev or Mariia Shvarnovna despite the fact that they are married to members of the dynasty.

\footnotetext{
5 The remaining women whose actions are mentioned (other than their marriage, birth of an heir, or death) are: Anna-Ianka, daughter of Yaroslav I who founds a monastic community in Kiev and becomes an envoy to Constantinople (Ch. 4, Degree III, eleventh century); Vasilisa, wife of Prince Andrei Konstanovich of Nizhnii Novgorod, who founds a monastery and is tonsured there (Ch.11, Degree XI, 14th century); Sofiia Vitovna, wife of Vasilii I, who travels to see her father the Grand Prince of Lithuania (Ch.12, 21, Degree XIII, turn of the fifteenth century); Iulianiia Viazemskaia, martyred in 1406 for trying to defend her chastity (Ch. 26, Degree XIII) and Elena Ivanovna, daughter of Ivan III, who retains the Orthodox faith after her marriage to Lithuanian prince Aleksandr (Ch. 25, Degree XV, fifteenth century).

6 A.S. Usachev, "K voprosu o datirovke Stepennoi Knigi," [On the Question of the Dating of the Book of Royal Degrees] in Drevniaia Rus'. Voprosy Medievistiki [Ancient Rus. Questions on Medieval Studies], 4/22 (2005): 35.
} 
To identify the spiritual significance of these particular Riurikid women to the SK's sixteenth-century Muscovite identity-building project, I suggest that female sanctity in the $S K$ can be approached fruitfully by looking beyond these epithets, and beyond a genealogy structured on bloodline. In her historical study of the royal women of Early Modern Russia, Isolde Thyrêt argues that in the sixteenth and seventeenth centuries, royal wives and mothers extended their dynastic position onto the spiritual landscape "by transcending the narrow biological definition of their motherhood and giving it a larger, religious meaning." " This article explores and develops Thyrêt's observation within the context of the $S K$, considering how conceptions of genealogy might be extended. The only element that these women all share, beyond being members of the dynasty, is that they are all founders of churches or monastic communities, or in other words the builders of holy sites. I would like to propose the existence of an alternate genealogical framework. This is not so much a biologically conceived lineage but a lineage defined by spiritual parameters, where sanctity is passed down in those dynastic figures who make possible the territorial concept of "Holy Rus": who are linked to the construction and consolidation of key holy loci.

Gail Lenhoff has noted the importance of the connection in the SK of the "chosen people," the Riurikids, with their "chosen land." 8 The first Degree presents the Old Testament covenants as antecedents to the Riurikid dynasty in Rus:

\section{Яко же семя Авраамле и Исаково и Израилево никто же не может исчести, тако и ВАадимира, новаго Израиля. ${ }^{9}$ \\ As the families of Abraham, Isaac and Israel can never die out, so [the family] of Vladimir, the new Israel.}

This essay examines the role of the royal holy women in situating sanctity within the "new Israel." It explores how the biological role of the royal women in the $S K$ is extended, and how they become

\footnotetext{
${ }^{7}$ Isolde Thyrêt, Between God and Tsar: Religious Symbolism and the Royal Women of Muscovite Russia (Illinois: Northern Illinois University Press, 2001), 16.

${ }^{8}$ G. Lenhoff, "Politics and Form in the Stepennaia Kniga," in The Book of Royal Degrees and the Genesis of Russian National Consciousness. UCLA Slavic Studies. New Series. 7, ed. Gail Lenhoff and Ann Kleimola (Bloomington: Slavica, 2011), 170.

9 SK Tom I, 334.
} 
significant not only physically because of their belonging to the dynastic family tree and their role in the production of heirs, but also symbolically because of the role they play in mapping, building and internalising a genealogy of sacred loci that come to define the physical and spiritual borders of Orthodox Muscovy.

I identify a shift in the rhetorical construction of the royal woman as geographic marker across the historical narrative of the SK, corresponding to the development of the geo-political imperatives of the emerging Muscovite State. The first twelve Degrees, which depict a period when the borders of Rus were not yet fixed, are characterized by an external focus beyond the borders of Rus or on marginal territories. The later Degrees represent a period when the state already begins to be centralized and political and religious power consolidated in Moscow, and they display an increasingly inwards-looking focus. Correspondingly, the symbolic connection between women and place is conceptualised differently. In the early Degrees, this link manifests itself through the trope of women founding and building churches, monasteries and towns, but in the later chapters the holy comes to be located internally within the dynasty, and the body of the royal woman begins to manifest itself as a holy locus.

\section{Building: The External Manifestations of Sanctity}

The historian N.N. Pokrovskii who contributed to the most recent edition of the $S K$ has suggested that the particular concentration of hagiographies in the earlier Degrees, particularly Degrees III-XII (spanning roughly the late eleventh century to the early fifteenth centuries) could be a method of allowing certain difficult historical events, such as the fighting among members of the dynasty that went on during the Kievan and Mongol periods, to be omitted or lightly passed over. ${ }^{10}$ An analysis of the accounts of royal women reveals that all accounts of more than a few lines occur before the end of Degree XII. I contend that the representations of royal women function to forge connections between disparate dynastic branches and demonstrate territorial unity in a period of dynastic conflict when both borders and bloodlines were unstable. This linking function manifests

${ }^{10}$ N. Pokrovskii, "Istoricheskie kontseptsii Stepennoi Knigi Tsarskogo Rodosloviia," [Historical Conceptions of the Book of Royal Degrees] in SK Tom I, 104. 
itself in two ways: through biological and familial connections, but also, significantly, through a connection with holy loci. The construction of an alternate genealogy based on spiritual geography strengthens and consolidates the Riurikid dynasty's claims to historic legitimacy.

\section{Constructing symbolic genealogies}

That the foundation of holy sites is crucial to the spiritual identity of the dynastic women in the $S K$ is evident through a comparison with prior accounts of these figures in earlier chronicles. The majority of narratives in the $S K$ are drawn from pre-existing sources, which are redacted to fit the context of the compendium. Of the four figures whom I discuss in this article, three are recorded in earlier sources. The Life of Evfrosiniia of Polotsk existed in three earlier redactions prior to its inclusion in the SK. ${ }^{11}$ The Life of Olga of Kiev is adapted and extended from the existing hagiography of her life. ${ }^{12}$ The account of Mariia Shvarovna was adapted from chronicle accounts. ${ }^{13}$ It is only the account of Evdokiia Donskaiia that is unique to the $S K{ }^{14}$ All three accounts undergo revision for their inclusion in the $S K$, and in all three cases an emphasis is placed on the royal woman's affinity with holy place, signifying her place in a symbolic lineage.

An analysis of pre-existing accounts of the Life of Olga reveals that the motif of founding and building holy sites takes on emphasis only in the sixteenth century. In hagiographic accounts which appear in

11 The Life of Evfrosiniia exists in four redactions in total, the earliest manuscript dating from the late fifteenth century. For dating and an analysis of the redactions see E.M. Voronova, "Zhitie Evfrosinii Polotskoi," [The Life of Evfrosiniia of Polotsk] in Slovar' Kniz̧nikov and Knizhnosti Drevnei Rusi Tom I [A Dictionary of Writers and Writing of Old Rus Vol. I], ed. Dmitrii Likachev (Leningrad: Academy of Sciences, 1987).

12 It is thought that the SK redaction of her life was composed by the Silvestr, a priest in the Kremlin Annunciation Cathedral, on the basis of the pre-existing account of her life in the Nikonovskaia Chronicle (second quarter of the sixteenth century). For a detailed analysis, see I.V. Kurukin, "Silvestr i sostavlenie Zhitiia Ol'gi Stepennoi knigi," [Silvestr and the Composition of the Life of Olga in the Book of Royal Degrees] in Teoriia i praktika istochnikovedeniia $i$ arkheografii otechestvennoi istorii, [Theory and Practice of the Study of Sources and Archeography in National History] (Moscow: Academy of Sciences, 1978), 51-60.

${ }^{13}$ For details of the sources, see SK Tom 3(Kommentarii) [Commentary], 102, 86-87, 112, 211.

14 Ibidem, 226. 
chronicles and church books prior to the sixteenth century, no mention is made of Olga founding the Church of the Holy Life-Giving Trinity or the town of Pskov, episodes central to the $S K$ narrative. ${ }^{15}$ The first mention of the foundation of the church, which occurs after Olga witnesses a miraculous vision, occurs in the so-called Pskovskaia redaction of the hagiography, which is included in the Great Menaion, the most exhaustive Muscovite hagiographic compendium of the sixteenth century. ${ }^{16}$ Significantly, the Pskovskaia redaction appears only in one version of this compendium: the so-called "Royal" (Tsarskii) redaction which was compiled in the 1550 s, only shortly before the $S K$, and was destined for the Tsar's palace in the Kremlin. These observations lead us to conclude that Olga's association with the foundation of holy sites in Rus becomes particularly pertinent during this period in the context of the Kremlin, the centre of both royal and religious power. Moreover, an examination of the additions and expansions between the Pskovskaia redaction of the Life of Olga of the 1550 s and the $S K$ version from the 1560 s demonstrate that the trope of building, in the SK's construction of Olga, becomes a metaphor for apostolicity, and a means of connecting her to the biblical apostles.

For example, in the introduction to Olga's hagiography, the $S K$ inserts a passage about St. Andrew the Apostle prophesying the conversion of Rus to Christianity. This account, whilst having no precedent in pre-existing versions of the Life of Olga, does has precedent in several major chronicles, including the Povest' Vremmenykh Let (Primary Chronicle) and is closest to the accounts in the Voskresenskaia Chronicle (sixteenth century) and the Nikonovskaia Chronicle (sixteenth century). ${ }^{17}$ The $S K$ adds several key elements not found in the chronicle sources. The earlier sources tell of Andrew's travels along the river Dniepr and the marking of the future site of Kiev with a cross and a blessing, after which he proceeds to Novgorod on

\footnotetext{
15 For an edition of the redactions of the Life of Olga, see the appendices in Aleksei Karpov, Kniaginia Ol'ga [Princess Olga], (Moscow: Molodaia Gvardiia, 2009).

16 A. Karpov, "Zhitie kniagini Ol'gi v redaktsii pskovskogo knizhnika Vasiliia (v inochestve Varlaama," [The Life of Princess Olga in the Redaction of the Pskovian scribe Vasilii (Varlaam in monastic life)], Ocherki feodal'noi Rossii [Studies of Feudal Russia] 7 (2003): 66-88.

17 Polnoe Sobranie Russkikh Letopisei [Full compendium of Russian Chronicles] (Hereafter PSRL), vol. 1, 7-9 (Povest' V remennykh Let), PSRL, vol. 7, 262-263 (Voskresenskaia Letopis'); PSRL, vol. 9, 3-4 (Nikonovskaia Letopis').
} 
the way to Rome. In the $S K$ version, however, Andrew travels along the Dniepr, arrives at the future location of Kiev where he prays, places a cross, delivers a blessing and, then, declares not only that Kiev will be built here, but that 'all the Rus land will undergo holy baptism'. The passage ends with the phrase:

Прообразоваше же божественымъ крестомъ в

Русьтеи земли священное чиноначалие. ${ }^{18}$

The celestial cross of St. Andrew was a sign that there would be a boly bierarchy in the lands of $\mathrm{Rus}$.

Here, the prophesy of the building of Kiev does not signify simply the founding and construction of the first Christian centre. Instead, the text extends the symbolism of the placing of the cross, connecting it to the spread of Christianity through the entire land of Rus. References to the "Rus land," which are not attested to in any of the earlier sources featuring St. Andrew, appear twice in this short passage in the Life of Olga. The passage serves as an excellent example of the function of the rhetoric of building within the wider project of the SK: to portray the broad expanse of Rus with its sacred sites, such as Kiev, as a Holy Land.

Olga's identity as an apostle is constructed in conjunction with this opening episode with St. Andrew. Like Andrew, Olga travels around the land, proselytising, visiting towns, destroying the pagan idols and erecting crosses in their place. ${ }^{19}$ The description of her prophecy and founding of the Church of the Life-Giving Trinity, and subsequently the town of Pskov, is a direct parallel to Andrew's prophecy about Kiev. Again, this passage is extended from the Pskvoskaia redaction, and insertions made which connect Olga not only to Pskov, but, as with Andrew, to the land of Rus more broadly, and its future baptism. Olga is described as the "grace and enlightenment of the Rus lands" (благодати и просвещения земли Русстей) and as "taking great care of the Rus lands" (велико попечение имея о соблюдении Руския земли). ${ }^{20}$

Olga is granted a privileged position in the symbolic lineage of apostles, and her foundation of one holy site becomes a metaphor for

\footnotetext{
18 SK Tom I, 151.

19 SK Tom I, 172.

${ }^{20}$ Ibidem, 172.
} 
the foundation of "Holy Rus." In a similar way, the account of the twelfth-century princess Mariia Shvarnovna in Degree VI similarly employs the motif of physical building in a wider symbolic sense. Mariia Shvarnovna, wife of Grand Prince Vsevolod, founded the female Assumption Monastery in Vladimir, known as the "Princess' Convent" because it became a burial place for dynastic women. In presixteenth- century chronicle accounts of Mariia, her foundation of a monastery does not take central stage. The $S K$ version copies the account of her life found in the Simeonovskaia Chronicle (end of the fifteenth century) and reorders the episodes to place emphasis on the foundation of the monastery and the procuring of land. ${ }^{21}$

Similar to the way in which the Life of Olga opens with the account of St. Andrew the Apostle, mirroring Olga's apostolic activities, the SK account opens with a comparison of Mariia to Abraham, the Old Testament patriarch who bought land on which his progeny could be buried, thus securing their inheritance and right to the land. In the fifteenth-century text the comparison with Abraham is present, but appears near the end of the passage, and is referenced specifically in connection only with the preparation of her grave. In relocating this comparison with Abraham to the opening passage, the $S K$ places greater symbolic significance on it. Moreover, the reference to Mariia's grave is removed, and the passage instead reads that she bought land 'in order to build a church and a monastery." 22 These changes endow Mariia's connection to Abraham with a wider significance, namely the provision of land for future generations of the dynasty more broadly. To strengthen this image, the $S K$ goes on to insert a list of the various dynastic members who were subsequently buried in the monastery and in which parts of the building they were buried, an addition which is unknown in earlier accounts. These edits and insertions to the text serve to locate Mariia simultaneously in two interconnected lineages: one symbolic, in which she continues the legacy of Abraham and one dynastic, in which she perpetuates future generations of the Riurikid bloodline through the provision of land.

The hagiography of princess Evfrosiniia of Polotsk presents another example of mutually reinforcing biological and geographic genealogies. Evfrosiniia was tonsured as a nun and went on to become abbess of

21 See PSRL, vol. 28, 41-41 (Simeonovskaia Letopis').

22 SK Tom I, 456. 
the Monastery of the Almighty Saviour and his Most-Pure Mother, which she founded in the second third of the twelfth century. Evfrosiniia does not figure in the genealogy of Ivan IV directly, seeing as she belongs to an offshoot of the main Riurikid dynasty and has no children. However, her hagiography presents her as part of two complementary lineages: one introducing her at the beginning of the text, and one summarising her achievements at the end:

Бысть князь в Полоцку именем Всеслав, сынъ Брячиславов, внук Изяславов, правнук блаженнаго и равноапостолнаго ВлаАимера. ${ }^{23}$

There was a Polotsk prince by the name of $V$ seslav, son of Briacheslav, grandson of Iziaslav, great grandson of the blessed 'equal-to-the-apostles'Vladimir.

Темже, братия, хвалится Селун о Амитрии, Вышегород - мученикома Борисом и ГАебом, аз же хвалю блаженый сей граА Полотцкий, такову меторасль возрастивши, преподобную Еуфросинию. ${ }^{24}$

As Thessalonika is glorified on account of Dmitrii, and Vyshgorod on account of the martyrs Boris and Gleb, I glorify this blessed town of Polotsk, which produced such an offspring: the venerable Evfrosiniia

The extended description of her biological lineage which appears in the introduction is, again, an insertion unique to the $S K$ redaction of her hagiography. Although Evfrosiniia is not part of the main branch of the Riurikid dynasty, her place in the $S K$ is legitimised by tracing her lineage back to Prince Vladimir. This establishes Riurikid rule over Polotsk, and includes the city among the loci sancta of "Holy Rus." Subsequently, there is an alternate 'genealogy' proposed in the final panegyric to Evfrosiniia. The main purpose of this concluding blessing is to position Evfrosiniia in an 'alternate lineage' of Orthodox saints who are connected firstly with particular holy places, and secondly with the dynasty. Dmitrii of Thessalonika is the patron saint of the Riurikid dynasty and was venerated by a succession of Kievan and Muscovite princes. Boris and Gleb are the first and most widely venerated saintly

23 SK Tom I, 434.

24 Ibidem, 447. 
princes in Rus. In this way Polotsk is included as part of the wider Orthodox, and specifically the Rus territory and dynastic landscape. Polotsk was a disputed territory all the way through the sixteenth century, constantly changing hands between Muscovy and the Grand Duchy of Lithuania. Ivan IV's armies took Polotsk in 1563, around the time of the $S K$ 's completion. The inclusion of Evfrosiniia's hagiography, then, is utilised as a method of linking or consolidating claims to territory both via a biological dynastic lineage, and also through an alternate 'saintly' lineage. Evfrosiniia is not a direct descendent of Dmitrii or Boris and Gleb. What is being passed on here is not blood, but sanctity and a connection with holy place.

\section{Building Miracles}

That the association with holy loci is particularly significant in the symbolic construction of the female members of the dynasty is evident in the nature of the miracles associated with them, in contrast to that of their male counterparts. For instance, both Olga's foundation of the church in Pskov and Evfrosiniia of Polotsk's construction of a female monastery are heralded by divine visions which indicates to them the divinely appointed site where they should build.

In the Life of Olga this vision is of three rays of light which illuminate the woods near the Pskov river. The crosses that she erects, marking the future foundation of many holy sites, produce "many miracles and signs even to this day." 25 In the Life of Evfrosiniia, the saint witnesses three visitations from an angel who leads her to a particular location in a nearby village, "a holy place... worthy of the Heavenly Kingdom," where she subsequently founds a female monastery. ${ }^{26}$ Subsequently, the building of the monastery and the miracles associated with it come to form the structural backbone of the entire hagiography. The first half of the hagiography focusses on the prophecy of and search for holy place. Evfrosiniia moves from her father's royal household, to a female monastic community, to a small cell in the basement of the cathedral church. However, the Bishop says that "it is not suitable" for her to stay there because it is a place where

25 SK Tom I, 172.

${ }^{26}$ Ibidem, 172. 
the lay people gather. ${ }^{27}$ This section is characterised by Evfrosiniia's inability to find a suitable holy location to accommodate her. As she demonstrates her worthiness as a saint through pious behaviour, the narrative builds up through the series of prophetic visions to the point of culmination, when she is finally granted the 'promised' land on which to construct the first monastery. The second half of her hagiography focusses on the physical construction and decoration of the monastery. The two miracles which occur at the monastery during Evfrosiniia's lifetime are both associated with the physical construction of the monastery buildings. The first occurs when the chief architect of the monastery church hears a voice telling him to get up and go quickly to build the church. The second occurs near to the completion of the church, when there are no more bricks left to finish the construction of it. After Evfrosiniia prays to the Lord, some bricks are miraculously discovered in a stove. ${ }^{28}$

In both these examples, the miraculous work of the saintly royal princess is connected to the foundation of or to the physical construction of the holy building. This is markedly different from the way in which Olga's grandson, Prince Vladimir, founds the first stone church in Kiev, the Church of the Dormition of the Virgin (Tithe Church) in Degree I. Vladimir does not experience a divine visitation or vision to help him determine where to build the church. In fact, it remains unclear how the decision of where to found the church is reached. Vladimir 'seeks advice from his most-holy father Metropolitan Leontii and from the bishops and boyars', and after much prayer and almsgiving they discovered a suitable place "by God's Will." ${ }^{29}$ Unlike Pskov, which is marked as a sacred site through Olga's direct communion with the divine through a vision, the Tithe Church's location is decided upon via Vladimir's council with the ecclesiastical authorities. Vladimir's affiliation with the motif of building is a demonstration of his power as head of state, operating in harmony with the Orthodox Church. In the case of Olga, Evfrosiniia and Mariia, the association with building is a manifestation of their symbolic capital. Their building projects form a continuity with Old Testament and New

\footnotetext{
27 Ibidem, 438.

28 SK Tom I, 440.

${ }^{29}$ Ibidem, 306.
} 
Testament figures, and act as a conduit to the divine by means of miraculous visions.

\section{Kiev-Vladimir-Moscow: shifts in the rhetoric of building}

As the Muscovite compilers traced the geo-political centre of Rus historically from Kiev, to Vladimir, and finally to Moscow, where political power comes to be consolidated, this shift is mirrored in the rhetoric of building in the accounts of the royal women from the Life of Olga up until Degree XII. The Life of Olga presents miracles associated predominantly with the prophecy of the 'building' of Orthodoxy and the land of Rus, providing the broad figurative framework for the conversion and establishment of Christianity throughout the Rus lands. In the Life of Evfrosiniia, miracles are associated more with the physical building process. Olga's hagiography prefigures and prophesies the material manifestation of holy places across a wide geographical area which the Muscovite elite sought to encompass as "Holy Rus." These early chapters focus on the establishment of the parameters of this land and the fixing of the centre and the periphery. They track both on the transfer of power between centres; from Kiev to Vladimir, which became the seat of the Grand Prince from the twelfth to the fourteenth centuries, and delineate the external borders of Rus by incorporating marginal territories, such as Polotsk.

By Degree XII (1359-1389) which recounts the early years of the Daniilovichi princes and the rise of Moscow, holy place along with political power is being consolidated in the future capital of Muscovy. In the account of Evdokiia, wife of Dmitrii Donskoi, which is unique to the $S K$, the rhetoric of building shifts once more, reflecting the new location of construction: Moscow.

In the account of Evdokiia, physical monuments carry less symbolic significance. The passage is entitled "On the establishment of holy churches and the foundation of the Ascension monastery." 30 The buildings she establishes are simply listed, their enumeration resembling a chronicle entry rather than a panegyric to and via great monuments. There are no miraculous visions or miracles described as part of the building process. In contrast with the holy royal women of Degrees III-

30 SK Tom II, 66. 
XI, the lack of detail in describing the foundation and construction of the religious institutions indicates that Evdokiia's patronage was not the primary reason for her holiness.

An examination of how the "holy sites" for the establishment of these buildings are chosen demonstrates that the locus of sanctity has shifted. The first church Evdokiia founds is in her own royal courtyard', dedicated to the Nativity of the Virgin and Lazarus. ${ }^{31}$ She then founds a church and a monastery in Pereiaslavl, and finally the Ascension Cathedral and convent, also in the Moscow Kremlin. The focus of her patronage localises sanctity within the parameters of the immediate residence of the Tsar. The trope which we observed in the Lives of Olga and Evfrosiniia is now transformed. Olga and Evfrosiniia commission and build the town of Pskov and the Polotsk monastery respectively on the sites where they witness a holy vision. They are responsible for locating sanctity and constructing shrines on the margins of the Rus land. Now construction is taking place in the centre of the land in the "Tsar's courtyard:" the Kremlin. The fact that there is no divinely inspired guidance to inform Evdokiia where to locate these buildings indicates that the "Tsar's courtyard" is already recognised as a holy site. The powers of the Church and the dynasty are now firmly located in the same place: the Kremlin walls contained both the princely residence as well as cathedral churches. In connection with this, other manifestations of sanctity, less connected with the rhetoric of building, take centre stage. The next section explores how in the later Degrees, the "building" of the holy comes to be expressed more abstractly in the accounts of royal women. The locus of the divine is presented less as contained by the walls of the churches of "Holy Rus" than by the flesh of the dynasty.

\section{Body: The Internal Manifestations of Sanctity}

Его же сосуда избра Господь вдовствена и целомудрена, премудрости и разума исполнена, и всюду кипяща Ауховным благовонием; еще же самодержавна, яко же вцастию земнаго царствия, выше же сих и наА страстьми телесными царствуя ${ }^{32}$

31 Ibidem, 66.

32 SK Tom I, 150. 
The Lord chose his vessel to be a widow, and to be chaste, filled with wisdom and reason, overflowing with heavenly incense; and she was also sovereign, having power over the earthly kingdom, yet even more than this reigning over the passions of the body.

The first lines of the Life of Olga identify the female body as a holy vessel - a locus of power that extends both over territorial dominion and the passions of the body. The female body is compared to a "kingdom" which can be ruled over, in the same way as Olga has dominion over the lands she rules. Throughout the $S K$, this relationship between body and territory is strengthened until the female body substitutes the geographical location as the site of the sacred.

The progressive internalization of the holy shift evidenced in comparisons between Olga and Evdokiia. The framework for their celebration is outwardly similar: both these princesses are venerated in their widowhood, after the deaths of their husbands, and are celebrated in particular for their chastity. However, the forms in which these shared topoi manifest themselves in each account is markedly different. One shared topos is the lament that they both perform to their dead husbands:

Olga: и восплакася вельми, глаголющи:... and she began to weep bitterly, saying:... ${ }^{33}$

Evdokiia: и восплакася горкимъ гласомъ, огненыя слезы изо очию испущающи, утробою распалающися и в перьси своя руками бьющи, и яко труба, рать поведающи, и яко арганъ, слаАко и жалостно вещающи сице:... and she began to weep with a bitter wail, fiery tears falling from her eyes, her womb on fire, beating her hands on her breast, and like a trumpet, calling the army to battle, and like an organ, she sweetly and pitifully announced:....34

There is a stark divergence here in the descriptions of their respective displays of distress. The account of Evdokiia highlights not only her verbal, but also physical reaction to Dmitrii's death which

33 SK Tom I, 153.

34 SK Tom II, 61. 
seems to overtake her entire body, including her internal organs. This highly physical response is completely absent in the account of Olga.

Both deathbed laments indicate the beginning of the princesses' respective journeys to acquire spiritual power. After her husband's death, Olga takes on the role of regent, ruling for her son Sviatoslav, who is still a minor. The function of Olga's lament in this context is to demonstrate the transition of her identity as wife to ruler, which involves the rejection of the female body:

И еАва плачю преставшу, по малу нача укреплятися, и женскую немощь забывши и мужеским смыслом обложися ${ }^{35}$

And when she had finished crying, she began to take on strength, and forgot her female weakness, and armed herself with manly wit

Subsequently, Olga consistently proves her control over bodily passions, specifically her chastity, through geo-political action. Her triumph over the enemy Derevliane is predicated upon her refusal to marry their leader. ${ }^{36}$ Her defeat and massacre of the tribe is framed as an act of revenge for her husband's death and a demonstration of her fidelity and purity. The political and religious connections she builds between Constantinople and Kiev are likewise predicated upon her refusal to marry the Tsar of Constantinople. ${ }^{37}$ By her refusal to marry, presented as proof of her chastity, she firstly defends her kingdom and secondly constructs religious and political links between Byzantium and Rus. Her spiritual power comes to be associated with defending borders and creating the perimeters for Rus.

In the case of Evdokiia, the relationship between body and territory has shifted. The deathbed lament establishes a precedent for female piety to be expressed precisely through the actions of the body. Evdokiia, like Olga, is described as a chaste widow. Yet instead of being made explicit through political action, her chastity is inscribed into her flesh. When she is accused by supposed slanderers in the court of being unchaste in her widowhood, the way in which Evdokiia proves her purity is by exposing her mutilated body to her sons:

\footnotetext{
35 SK Tom I, 154.

36 SK Tom I, 154-156.

37 Ibidem, 163.
} 
И отверзе мало одеже своея свыше, иже от перьсеи, и показа имъ малу часть телеси утробы своея...яко оть огня ожжене быти плоти ея, и почернети, и къ костемъ прилпене ${ }^{38}$

And she undid her clothes a little, from the breast down, and showed them a small part of her stomach...her flesh was as if it had been scorched by fire; blackened, and clinging to the bones

This visceral description of the ascetic body is something not encountered in the prior accounts of royal women. In the account of Evdokiia, the female body becomes the focal point for the veneration of the figure as holy. The parameters of the holy have shrunk. Rather than the female saint constructing the perimeters of the holy in the walls of the sites she builds, the perimeters have become the flesh of her body. This transition is made particularly explicit when a comparison is drawn between the miracles performed by Evdokiia and those in the accounts of Olga or Evfrosiniia. Rather than involving visions of the foundation of churches or the miraculous appearance of bricks, Evdokiia's miracles manifest themselves entirely through her speech, gesture, and touch.

Unlike her predecessors, Evdokiia does not travel to or acquire holy objects from Constantinople in order to legitimise the sanctity of her churches and monasteries. Olga brings part of the True Cross from Constantinople to Kiev, and Evfrosiniia decorates her monastery with an icon of the Mother of God of Ephesus sent by the Byzantine Emperor. Evdokiia, however, after experiencing a miraculous vision of the Archangel Michael, commissions and plays an instrumental role in the making of a new icon. The holy image which she chooses to place in her new church represents less the continuation of a spiritual tradition linking Constantinople and Moscow than a direct personal link with the divine experienced by a member of the Muscovite ruling dynasty. After she sees the angel, she undergoes a physical transformation and becomes mute for several days afterwards. Through a series of hand gestures, she bids an icon of the angel be drawn. This process of gesturing is repeated three times until the true image of the Archangel Michael is produced. At this point, "as soon as the blessed one saw the image, the knot of her tongue came undone, and she began

38 SK Tom II, 68. 
to speak clearly." 39 Rather than gaining access to holy objects by means of political ties and envoys, Evdokiia quite literally channels the power of the divine through her body so as to produce the form of the angel on the icon. She becomes the conduit through which the divine is manifested.

The body of the princess as the location for the holy is confirmed in the final miracle Evdokiia performs before her death. This happens within the Kremlin, as she is walking from the palace to be tonsured in the Ascension Monastery that she founded. As she walks, a blind man calls out to her for aid, and she "lets the sleeve of her robe fall from her hand onto the ground." 40 The blind man grabs onto her sleeve, and is healed. Hereafter, some thirty people, suffering from various illnesses, are healed by Evdokiia before she reaches the monastery to be tonsured. The healing of these people does not take place inside any religious building, neither within a monastery or a church. The miracles take place between the ecclesiastical and the royal, as she is stopped in her path "from the Tsar's palace to the monastery." 41 Evdokiia forms a physical connection between the Church and the palace within the newly built space of the Kremlin, the unified centre of land, faith, and dynasty. ${ }^{42}$ If her involvement in the sanctification of the Kremlin is first demonstrated by the building of the Church of the Nativity of the Virgin and the Ascension Monastery, then in this final passage, the locus of sanctity is removed from within the walls of these edifices and becomes clearly located within the body of Evdokiia, as the vessel that enables the unification of dynastic continuity and divine grace.

After Degree XII, which ends with Evdokiia's death in 1407, accounts of women decrease dramatically. In the few that remain, a new trend emerges, shrinking the parameters of the female holy even further. In Degree XV, which covers the period of the reign of Ivan III (1462-1505), Sofiia Paleolog, wife of Ivan, makes a pilgrimage to the monastery of St. Sergei of Radonezh in order to pray for the birth of a son. On the way, she sees a vision of St. Sergei, who is carrying a boy-

\footnotetext{
39 SK Tom II, 68.

40 Ibidem, 69.

41 Ibidem, 69.

42 The first stone curtain wall of the Kremlin was constructed in the fourteenth century, during the reign of Dmitrii Donskoi. For information, see M. Paul, "The Military Revolution in Russia 1550-1682," The Journal of Military History 1/ 68 (2004): 31.
} 
child in his arms. He throws the child into her robes, and she tries to catch it. Although she searches among her robes, she cannot feel where the baby went. This vision is hailed as a miracle after Sofiia gives birth to the future Grand Prince Vasilii III, father of Ivan IV.

This hagiographic topos of the miraculous conception appears here for the first time in the SK. It is now not simply the body of the female ruler which is conceived of as a holy locus, but more specifically, as Isolde Thyrêt phrases it: "the Tsaritsa's Blessed Womb."43 Thyrêt remarks that Sofiia's experience of miraculous conception is paralleled to that of the Virgin, as she gives birth to Vasilii on March $25^{\text {th }}$, the feast of the Annunciation. ${ }^{44}$ She concludes that this episode "not only reflects Sofiia's notion of her son's divinely approved succession to the throne...but also seeks to portray her as a vessel of the divine." 45 The perimeters of holy place that the female ruler defines for the divine to inhabit are the walls of her womb.

\section{Conclusion}

In Degree XIII, wishing to defend her marriage and her chastity, Iulianiia Viazamskaia is represented as resisting the sexual advances of Iurii Sviatoslavich, Prince of Smolensk, at a feast, whereupon he rapes her. In his anger, he murders her husband and has Iulianiia's hands and feet cut off. The narrative presents his crime as the reason why the territory of Smolensk is then lost to the Lithuanians:

И таковымъ тогАа неправденымъ похыщениемъ Витофть Смоленское великое княжение из Руськиа Аержавы исторже къ своеи Аитовьскои области. ${ }^{46}$

And as a result of that unrighteous ravishment, Vitoft' (Ruler of Lithuania) wrested the great kingdom of Smolensk from the kingdom of Rus to make it part of his Lithuanian region.

Throughout the SK, the female body and the territory of Rus are conceptualized and constructed in tandem. This short narrative demonstrates that the purity and integrity of the former is crucial to the

\footnotetext{
43 The title of Chapter I of her monograph.

44 Thyrêt, Between God and Tsar, 28.

45 Ibidem, 27.

46 SK Tom II, 115.
} 
integrity of the latter. The identities of the royal women in the $S K$ as wives, mothers, and daughters of the dynastic princes are perceived to be significant beyond ties of blood and marriage, being situated within the domain of the spiritual through their connection with holy place.

The $S K$ seeks to present an immaculate genealogy for the first Muscovite Tsar, Ivan IV, uniting dynasty, land and faith. The early Degrees present a period in Rus history when borders were not fixed and linear succession had not been established, and it is in this context that, through building motifs, physical parameters come to form the structural framework for the veneration of the royal women, enabling alternate spiritual genealogies to be enunciated.

An analysis of the construction of holy place in the accounts of these women allows us to trace the progressive centralisation of spiritual and political authority in Moscow, portrayed through the changing manifestations of female sanctity. The terms of the veneration of the royal women move with the geo-political imperatives of the $S K$. The baptism of Rus is depicted through the veneration of Olga as a prophetic marker of holy sites. The extension of the lands of Rus, and the actualisation of the building of the faith, are represented through the veneration of royal women building in marginal and disputed territories. Finally, the consolidation of political power under one ruler in Moscow, and the union of Church and State finalised there in the Kremlin is made manifest in the body, and eventually the womb, of the royal woman carrying the holy Muscovite autocrat.

Genealogies are not only structured on bloodlines, and the SK least of all. The royal women of the dynasty figure as carriers not only of royal heirs but also of sanctity and signifiers in the narrative of preordained Riurikid rule, culminating in the coronation of the divinely appointed Tsar. In conjunction with the imperatives of this narrative, varied images of female sanctity flourish, and form part of a unique "history" where both holy royal men and women define and embody "Holy Rus." 


\section{References}

\section{Primary Sources}

Polnoe Sobranie Russkikh Letopisei [Full compendium of Russian

Chronicles]. 43 vols. to date. St. Petersburg-Moscow, 1846-2004. Stepennaia Kniga Tsarskogo Rodosloviia po drevneishim spiskam, [The Book of Degrees of the Royal Genealogy: a Critical Edition Based on the Oldest Known Manuscripts], ed. Gail D. Lenhoff and Nikolai N. Pokrovskii. 3 vols. Moscow: "Languages of Slav Cultures," 2007.

\section{Secondary Literature}

Bogatyrev, S. "Ivan IV (1533-1584)." In The Cambridge History of Russia Volume I: From Early Rus' to 1689, ed. Maureen Perrie, 240-263. Cambridge: Cambridge University Press, 2006.

Bushkovitch, Paul. Religion and Society in Russia: The Sixteenth and Seventeenth Centuries. New York: Oxford University Press, 1992. Elsner, J. "The Rhetoric of Buildings In the De Aedificiis of Procopius." In Art and Text in Byzantine Culture, ed. Liz James. Cambridge: Cambridge University Press, 2007.

Karpov, Aleksei. Kniaginia Ol'ga [Princess Olga]. Zhizn' zamechatel'nykh liudei [Lives of Incredible People]. Moscow: Molodaia Gvardiia, 2009. . "Zhitie kniagini Ol'gi v redaktsii pskovskogo knizhnika Vasiliia (v inochestve Varlaama" [The Life of Princess Olga in the redaction of the Pskovian scribe Vasilii (Varlaam in monastic life)]. Ocherki feodal'noi Rossii [Studies of Feudal Russia] 7 (2003): 66-88.

Kurukin, I.V. "Silvestr i sostavlenie Zhitiia Ol'gi Stepennoi knigi" [Silvestr and the composition of the Life of Olga in the Book of Royal Degrees]. In Teoriia i praktika istochnikovedeniia $i$ arkheografii otechestvennoi istorii, [Theory and Practice of the Study of Sources and Archeography in National History], ed. Vladimir Pashuto, 51-60. Moscow: Academy of Sciences, 1978.

Lenhoff, G. "Politics and Form in the Stepennaia Kniga." In The Book of Royal Degrees and the Genesis of Russian National Consciousness, ed. Gail Lenhoff \& Ann Kleimola, 157-174. UCLA Slavic Studies, New Series, 7. Bloomington: Slavica, 2011. 
. "Unofficial Veneration of the Daniilovichi in Muscovite Rus." In Culture and Identity in Muscovy: 1359-1584, ed. Gail Lenhoff and Ann Kleimola, 391-416. UCLA Slavic Studies, New Series, 3. Moscow: IZZ-Garant, 1997.

Miller, D. B. "The Velikie Minei Chetii and Stepennaia Kniga of Metropolitan Makarii and the origins of Russian national consciousness." Forschungen zur Osteuropäischen Geschichte 26 (1979): 263-373.

Paul, M. "The Military Revolution in Russia 1550-1682." The Journal of Military History 1/68 (2004): 9-45.

Pokrovskii, N. "Istoricheskie kontseptsii Stepennoi Knigi Tsarskogo Rodosloviia" [Historical Conceptions of the Book of Royal Degrees]. In Stepennaia Kniga Tsarskogo Rodosloviia po drevneishim spiskam [The Book of Degrees of the Royal Genealogy: a Critical Edition Based on the Oldest Known Manuscripts], vol.1, ed. Gail D. Lenhoff and Nikolai N. Pokrovskii, 104. Moscow: "Languages of Slav Cultures," 2007.

Thyrêt, Isolde. Between God and Tsar: Religious Symbolism and the Royal Women of Muscovite Russia. Illinois: Northern Illinois University Press, 2001.

Usachev, A.S. "K voprosu o datirovke Stepennoi Knigi," [On the question of the dating of the Book of Royal Degrees]. Drevniaia Rus'. Voprosy Medievistiki [Ancient Rus. Questions on Medieval Studies] 4/22 (2005): 35.

Voronova, E.M. "Zhitie Evfrosinii Polotskoi" [The Life of Evfrosiniia of Polotsk]. In Slovar' Kniz̧hnikov and Kniz̧hnosti Drevnei Rusi Tom I [A Dictionary of Writers and Writing of Old Rus Vol. 1], ed. Dmitrii Likachev. Leningrad: Academy of Sciences, 1987. 